\title{
KLIMATSKA POGOJENOST DEBELINSKEGA PRIRASTKA DREVES OB SLOVENSKIH VISOKOGORSKIH ALPSKIH JEZERIH
}

\author{
Darko Ogrin*
}

Izvleček

UDK 630*17:551.583(234.3 Julijske Alpe)

S standardnimi dendrokronološkimi in dendroklimatološkimi postopki smo iz pojezerij Jezera na Planini pri jezeru, Jezera $v$ Ledvicah in Krnskega jezera $v$ Julijskih Alpah analizirali približno 100 vzorcev smrek in macesnov. Lokalne kronologije zajemajo v glavnem obdobje po letu 1920. Korelacija debelinskega prirastka s klimatskimi podatki je potrdila določena splošna spoznanja o odnosu med podnebjem in prirastjo $v$ območjih ob zgornji gozdni meji, hkrati pa pokazala na svojski vpliv lokalnih, tudi neklimatskih dejavnikov priraščanja, ki jih $z$ dendroklimatološko analizo ni mogoče zadovoljivo zajeti.

Ključne besede: dendrokronologija, dendroklimatologija, debelinski prirast dreves, zgornja gozdna meja, Julijske Alpe, Slovenija

CLIMATIC CONDITIONING OF RADIAL INCREMENTS OF TREES NEAR SLOVENIAN

HIGH-MOUNTAINOUS ALPINE LAKES

Abstract:

Analysed by means of standard dendrochronological and dendroclimatological processes were about 100 spruce and larch samples from the lake areas of Jezera on Planina pri Jezeru, Jezera $v$ Ledvicah and Krnsko Jezero, all in the Julian Alps. Local chronologies mainly include the period from 1920 onwards. Correlation between radial increments and climatic data confirmed certain general anticipations about the relation between climate and increments in the upper forest-line zone, and concurrently exposed the specific influence of local, including non-climatic factors on the growth which can not be satisfactory comprised in dendroclimatological analysis.

Key words: dendrochronology, dendroclimatology, trees' radial increment, tree line, Julian Alps, Slovenia

\footnotetext{
* Dr. geografije, Oddelek za geografijo, Filozofska fakulteta, Aškerčeva cesta 2, 1000 Ljubljana, Slovenija, E-mail: Darko.Ogrin @ FF.UNI-LJ.SI
} 


\section{UVOD}

Nekaj raziskav odnosov med širino letnic in podnebjem v Julijskih Alpah je bilo že opravljenih. Ogrin (1992) je raziskoval vpliv padavin in temperatur na debelinski prirast smrek in macesnov s Komne in Vršiča, zunaj Julijskih Alp tudi s Krvavca in Uršlje gore. Raziskava je sicer potrdila določena splošna spoznanja o odnosu med debelinskih prirastkom in podnebjem ob zgornji gozdni meji, hkrati pa nakazala potrebo po nadaljnjih tovrstnih raziskavah zaradi specifičnega pomena lokalnih, tudi neklimatskih dejavnikov priraščanja, ki lahko splošno shemo bistveno spremenijo ali celo prekrijejo.

$\mathrm{V}$ prispevku so prikazani rezultati raziskave, ki je potekala $\mathrm{v}$ pojezerju Jezera na Planini pri Jezeru, Jezera $v$ Ledvicah in Krnskega jezera. Raziskava je del širše zasnovanega projekta »Slovenska alpska jezera: ekologija in paleoekologija«, ki jo vodi Inštitut za biologijo v Ljubljani (Laboratorij za raziskovanje sladkovodnih in kopenskih ekosistemov). Namen raziskave je bil s pomočjo drevesnih letnic ugotoviti ujemanje sprememb v okolju, ki vplivajo na debelinski prirast, predvsem klime, s procesi, ki potekajo oziroma so potekali v zadnjem stoletju v omenjenih jezerih.

\section{OBMOČJE RAZISKAVE}

Pojezerja Jezera na Planini pri Jezeru, Jezera v Ledvici in Krnskega jezera ležijo ob južnem robu Julijskih Alp. Planina Jezero leži na visokogorski kraški planoti na nadmorski višini približno $1450 \mathrm{~m}$. V osnovi je pojezerje zgrajeno iz triasnega apnenca in dolomita in je močno ledeniško preoblikovano. Posledica zadnje poledenitve so številni morenski nasipi in ledeniško-kraške kotanje. V eni od njih se je obdržalo tudi jezero. Ledeniškega nastanka je tudi Krnsko jezero. Jezersko kotanjo je izdolbel ledenik s Krna v srednjem delu obvisele doline, kjer so bili apnenci manj čisti. Jezero se je ohranilo na dnu zakrasele in stopnjaste doline med Velikim Lemežem in Malim Šmohorjem na nadmorski višini 1394 m. Jezero v Ledvicah je eno od sedmih jezer, ki so nastala v Dolini Triglavskih jezer. Leži v kotanji med Velikim Gradom in Malo Zelnarco na nadmorski višini $1831 \mathrm{~m}$. Dolina Triglavski jezer je ledeniškega nastanka, poteka pa v smeri SV-JZ. Vrhovi nad njo se dvigajo nad $2000 \mathrm{~m}$ visoko. S pobočij se spuščajo obsežna melišča, ki so ponekod prekrila tudi dolinsko dno. Precej površja prekriva tudi živoskalna apnenčasta osnova s številnimi visokogorskimi kraškimi pojavi, predvsem škrapljami in žlebiči.

Podnebje pojezerij je gorsko, s povprečnimi januarskimi temperaturami okoli $-4{ }^{0} \mathrm{C}$ in julijskimi med 10 in $12{ }^{\circ} \mathrm{C}$ ter veliko namočenostjo. V povprečju pade letno 3000 in 
več mm padavin, največ v jesenskih mesecih. Več padavin pade v pojezerju Krnskega jezera, nekoliko manj pa v Fužinskih planinah, kjer je Jezero na Planini pri Jezeru. JV predgorje Julijskih Alp poraščajo bukovi, bukovo-jelovi, bukovo-macesnovi in smrekovi gozdovi, ki so bili v preteklosti skrčeni in spremenjeni zaradi fužinarstva, gozdarjenja in urejanja pašniških planin. Nabiranje vzorcev za raziskavo je potekalo $\mathrm{v}$ bližini zgornje gozdne meje, kjer sta prevladujoči drevesni vrsti smreka (Picea abies) in macesen (Larix europea). Okolici Jezera na Planini pri Jezeru in Krnskega jezera sta še vedno aktivni planini, $v$ Dolini Triglavskih jezer pa paša zaradi lege $\mathrm{v}$ Triglavskem narodnem parku ni več dovoljena.

\section{MATERIAL IN METODE}

Smreke in macesni, ki smo jih vzorčili za raziskavo, rastejo na precej različnih rastiščih. Na Planini pri Jezeru prevladujejo manjša fosilna melišča in morensko gradivo, ko se spuščajo $\mathrm{v}$ jezersko kotanjo. Melišča in morene so prekrite s tanko rendzino, ki je ponekod nesklenjena. Gole živoskalne osnove je malo. Prevladuje južno od Jezera v Ledvicah, kjer smo vzorčili macesne. Gre za značilen visokogorski kraški svet z globokimi škrapljami in žlebiči, kjer je prst le v žepih škrapelj. Podobne razmere so JZ od Krnskega jezera, kjer smo na pregibu krnice pod Krnom (Planina na Polju) proti kotanji Krnskega jezera vzorčili macesne in južno od Koče pri Krnskih jezerih, kjer smo na zakraselem pomolu vzorčili smreke. Tudi tu gre za škrapljast in žlebičast teren, le da je prst nekoliko debelejša in bolj sklenjena.

Za vzorčenje (z vsake lokacije po okoli 20 smrek in macesnov) smo izbirali odrasla, bolj na samem rastoča drevesa brez vidnih mehanskih in drugih poškodb in $\mathrm{z}$ neutesnjenimi krošnjami. Vzorce smo jemali z gozdarskim prirastnim svedrom $\mathrm{v}$ standardni prsni višini. Vrtali smo do stržena $\mathrm{z}$ dveh nasprotnih strani vzporedno $\mathrm{s}$ potekom plastnic terena. Zračno suhe vzorce smo nato zbrusili in jim s pomočjo lupe zmerili širino letnic na $1 / 100 \mathrm{~mm}$ natačno. V nadaljevanju smo sledili standardnim dendrokronološkim in dendroklimatološkim postopkom (Fritts, 1976; Huges s sod., 1982; Cook in Kairiukstis, 1990; Ogrin, 1989). S križnim datiranjem smo ugotavljali sinhronost priraščanja in zaradi večjih anomalij iz nadaljnje obdelave izločili 19 od skupno 108 vzorcev. Pri križnem datiranju smo si pomagali z t.i. vodilnimi kronologijami. Sledila sta datiranje in standardizacija, s pomočjo katerih smo odstranili biološki trend rasti. Uporabili smo »metodo koridorja« (Shiyatov, 1987; cit. po Cook in Kairiukstis, 1990), kjer smo vsaki kronologiji določili maksimalno in minimalno možno prirastno krivuljo in nato za vsako leto izračunali indeks širine letnic. Iz posameznih očiščenih, sinhroniziranih in standardiziranih kronologij smo sestavili povprečno lokalno kronologijo indeksov širin drevesnih letnic. Klimatski signal, zapisan v letnicah, smo razkrivali s korelacijo in odzivnimi funkcijami. Pri tem smo uporabili 13-mesečno obdobje od septembra preteklega leta do septembra tekoče 
rastne sezone. Za značilne smo jemali korelacije, ki so bile večje oziroma manjše od $+-0,25$. Kot vir klimatskih podatkov nam je služila bližnja meteorološka postaja Dom na Komni (nadmorska višina 1520 m). Podatki so bili za referenčno obdobje 19611990 (Klimatografija Slovenije - temperatura zraka 1961-1990, 1995; Klimatografija Slovenije - padavine 1961-1990, 1995).

Tabela 1: Nekateri podatki o vzorčenih drevesih. Table 1: Some data about sampled trees.

\begin{tabular}{|c|c|c|c|c|c|}
\hline Lokaciia & \multicolumn{2}{|c|}{ PLANINA JEZERO } & & & LEDVICA \\
\hline & 21 & 19 & 24 & 20 & 24 \\
\hline Povp. obseg & $147,5 \mathrm{~cm}$ & $118,1 \mathrm{~cm}$ & $146,7 \mathrm{~cm}$ & $110 \mathrm{~cm}$ & $112 \mathrm{~cm}$ \\
\hline Maks. obseg & $203 \mathrm{~cm}$ & $154 \mathrm{~cm}$ & $228 \mathrm{~cm}$ & $144 \mathrm{~cm}$ & $157 \mathrm{~cm}$ \\
\hline Min. obseg & $118 \mathrm{~cm}$ & $99 \mathrm{~cm}$ & $107 \mathrm{~cm}$ & $77 \mathrm{~cm}$ & $86 \mathrm{~cm}$ \\
\hline Višina dreves & $15-25 \mathrm{~m}$ & $15-25 \mathrm{~m}$ & $15-21 \mathrm{~m}$ & $15-20 \mathrm{~m}$ & $10-15 \mathrm{~m}$ \\
\hline Skalovitost & $10 \%$ & $15 \%$ & $20 \%$ & $25 \%$ & $75 \%$ \\
\hline
\end{tabular}

\section{REZULTATI}

\subsection{Lokalne kronologije}

Za pojezerji Jezera na Planini pri Jezeru in Krnskega jezera smo sestavili lokalni kronologiji za smreke in macesne, za pojezerje Jezera v Ledvicah pa le macesnovo kronologijo. Pri jemanju vzorcev smo pazili, da so bile enakomerno upoštevane vse rastiščne razmere na posameznih lokacijah, tako po talni osnovi, ekspoziciji in reliefnih značilnostih. S tem se $\mathrm{v}$ lokalnih kronologijah zrcalijo povprečne rastne razmere določene lokacije.

Za sestavo kronologij smo uporabili le neprizadeta in zmerno prizadeta drevesa, izločili pa vzorce $\mathrm{z}$ močnim upadom prirastka ter manjkajočimi letnicami. Lokalni kronologiji za smreke s Planine pri Jezeru sta dolgi 74 let in zajemata časovno obdobje od leta 1921 do 1995. Globina vzorca (število, ki pove, koliko posameznih vrednosti je bilo v kakem letu podlaga za povprečno vrednost) je bila pri smrekah po letu 1935 med 14 in 21, pred tem med 6 in 14, pri macesnih pa med 12 in 19. Podobnost med kronologijama ni velika $(r=0,4073)$. 
Slika 1: Smrekovi dendrokronologiji.

Figure 1: Dendrochronologies of spruces.

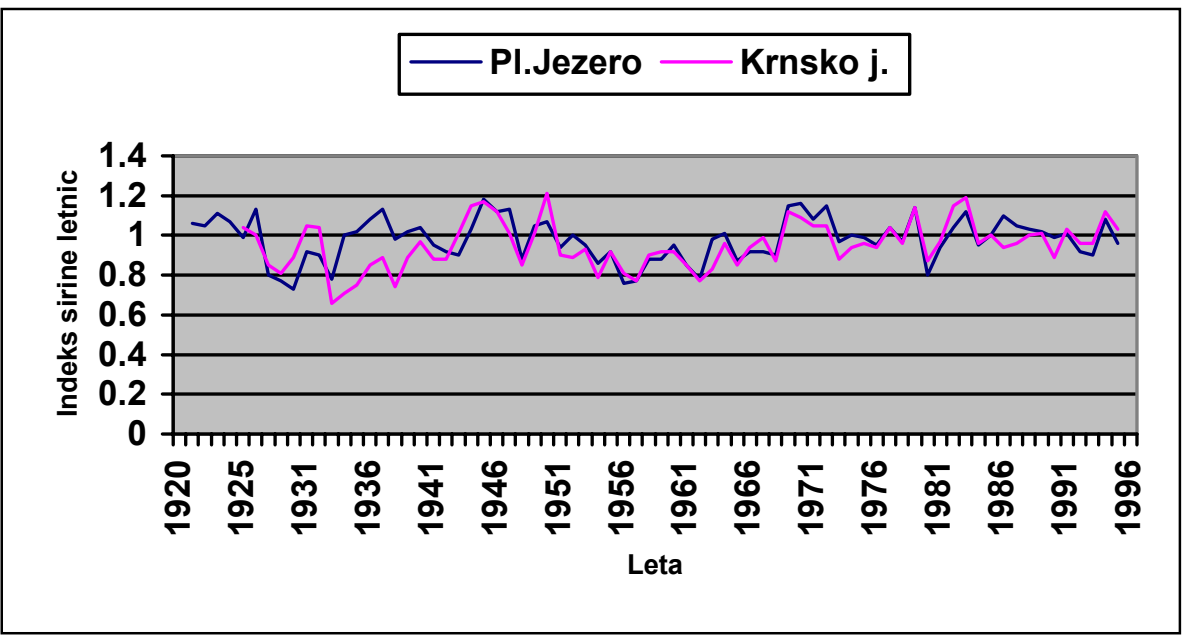

Tabela 2: Osnovni podatki o lokalnih kronologijah.

Table 2: Basic data on local chronologies.

\begin{tabular}{|c|c|c|c|c|c|}
\hline & \multicolumn{2}{|c|}{ PLANINA JEZERO } & \multicolumn{2}{|c|}{ KRNSKO JEZERO } & \multirow{2}{*}{$\begin{array}{l}\text { LEDVICA } \\
\text { Macesni }\end{array}$} \\
\hline & Smreke & Macesni & Smreke & Macesni & \\
\hline Časovni interval & $1921-1995$ & 1921-1995 & $1925-1996$ & 1901-1996 & 1861-1996 \\
\hline Dolžina kronologije & 74 let & 74 let & 71 let & 95 let & 135 let \\
\hline Št. dreves v analizi & 21 & 19 & 19 & 14 & 16 \\
\hline Povp. širina letnice & $2,76 \mathrm{~mm}$ & $1,92 \mathrm{~mm}$ & $2,44 \mathrm{~mm}$ & $2,12 \mathrm{~mm}$ & $1,17 \mathrm{~mm}$ \\
\hline Minimalna vrednost & $0,44 \mathrm{~mm}$ & $0,18 \mathrm{~mm}$ & $0,12 \mathrm{~mm}$ & $0,08 \mathrm{~mm}$ & $0,08 \mathrm{~mm}$ \\
\hline Maksimalna vrednost & $7,36 \mathrm{~mm}$ & $7,20 \mathrm{~mm}$ & $6,12 \mathrm{~mm}$ & $6,72 \mathrm{~mm}$ & $4,60 \mathrm{~mm}$ \\
\hline
\end{tabular}

Podobno dolga kot smrekova kronologija s Planine pri Jezeru je dolga tudi smrekova kronologija s pojezerja Krnskega jezera (71 let, 1925-1996). Globina kronologije je za čas po letu 194015 do 19, pred tem letom pa med 9 in 15. Macesnova kronologija za Krnsko jezero je daljša (95 let) in zajema obdobje od leta 1901 do 1996. Njena globina je med 6 in 14, s tem da je zanesljivejša po letu 1928, ko je globina nad 8 . Kronologiji s Krnskega jezera sta si precej podobni $(\mathrm{r}=0,5825)$, koeficient $\mathrm{t}$ po Baillie-Pilcherju (1973) - korelacijski koeficient korigiran s kvadratnim korenom 
števila stopinj prostosti - pa večji od 8, kar nam omogoča izračun povprečne kronologije za obe drevesni vrsti.

Najdaljša od vseh je macesnova kronologija s pojezerja Jezera v Ledvicah. Dolga je 135 let in zajema obdobje od leta1861 do 1996. Do leta 1880 je njena globina med 7 in 11 , po tem letu pa med 12 in 16 . Kronologija je precej podobna obema že predstavljenima macesnovima kronologijama, kaj malo skupnega pa ima $\mathrm{s}$ smrekovima kronologijama. Prav premajhna podobnost vseh kronologij, ki smo jo dobili z navkrižnim primerjanjem, nam je preprečila namero, da bi sestavili regionalno kronologijo za vsa tri pojezerja.

Slika 2: Macesnove dendrokronologije.

Figure 2: Dendrochronologies of larches.

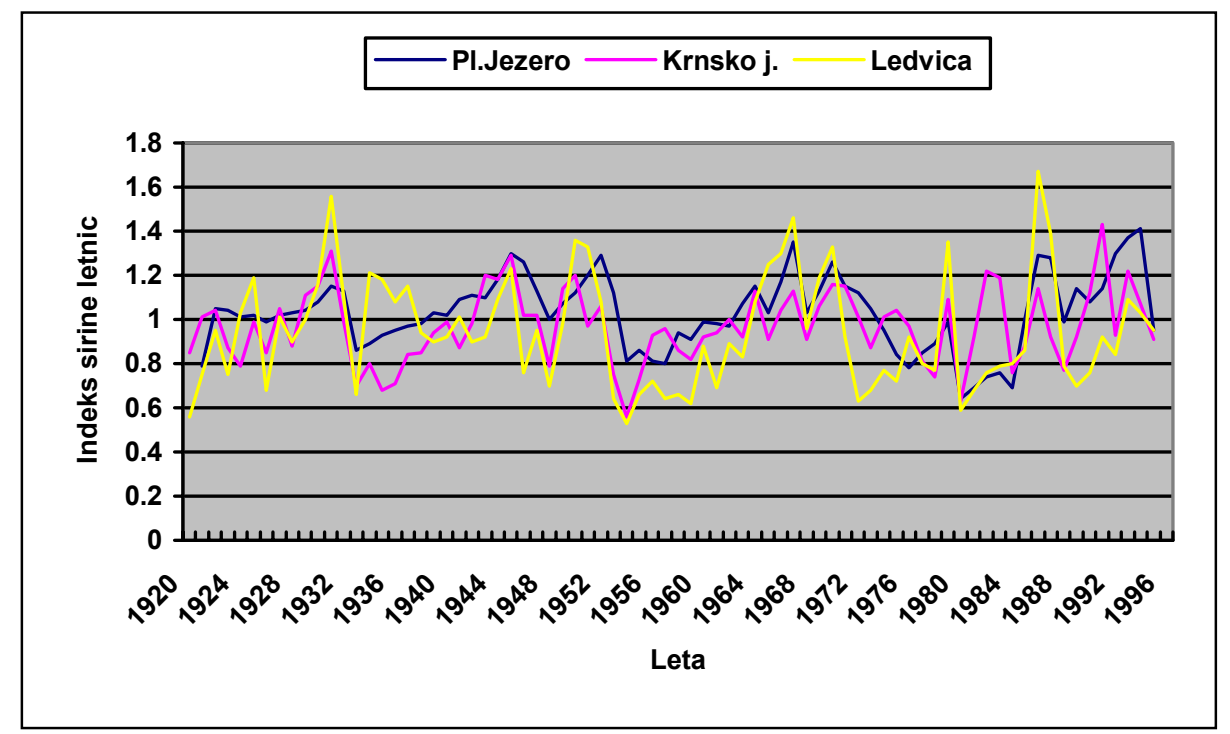

\subsection{Odvisnost debelinskega prirastka od temperature in padavin}

\subsubsection{Smreke}

Kljub veliki podobnosti med smrekovima kronologijama s Krnskega jezera in Planine pri Jezeru je odziv na podnebne razmere $\mathrm{v}$ določeni meri neenoten, predvsem pa neuravnotežen. Smreke s Planine pri Jezeru kažejo veliko odzivnost in trdne zveze s podnebjem, zlasti s temperaturo, pri Krnskem jezeru je značilnih korelacij manj, zveze so tudi manj trdne. Pri temperaturi smo pri Krnskem jezeru izračunali trdno 
zvezo $\mathrm{z}$ julijsko $(\mathrm{r}=0,4227)$ in februarsko temperaturo $(\mathrm{r}=-0,2953)$, na meji značilnosti pa je zveza s poletno temperaturo. Pri Planini Jezero je temperatura pomembna skoraj $\mathrm{v}$ vseh letnih časih, zlasti poleti $(\mathrm{r}=0,8332)$ in $\mathrm{v}$ celotnem obdobju od aprila do septembra, prav tako pa tudi $\mathrm{v}$ jeseni preteklega leta $(\mathrm{r}=0,6676)$ in pozimi $(r=-0,3302)$. Visoka je tudi zveza med širino letnic in povprečno letno temperaturo $(\mathrm{r}=0,7221)$.

Padavine imajo manjši pomen za debelinski prirastek, zlasti na Planini Jezero. Tu smo izračunali negativne korelacije s padavinami oktobra in decembra preteklega leta ter pozitivno s padavinami tekočega februarja in aprila ter novembra preteklega leta. Pri Krnskem jezeru so značilne korelacije tri, vse negativne: za julijske in septembrske padavine ter za padavine $\mathrm{v}$ vegetacijski dobi $(\mathrm{r}=-0,4649)$.

Tabela 3: Rezultati korelacijske analize - smreke.

Table 3: Correlation analysis results - spruces.

\begin{tabular}{|c|c|c|c|c|}
\hline $\mathbf{N}=\mathbf{3 0}$ & \multicolumn{2}{|c|}{ PLANINA JEZERO } & \multicolumn{2}{|c|}{ KRNSKO JEZERO } \\
\hline $1961-1990$ & Padavine & Temperatura & Padavine & Temperatura \\
\hline - SEP. & $-\mathbf{0 , 0 3 3}$ & $\underline{0,5006}$ & $-0,0152$ & $-0,0288$ \\
\hline - OKT. & $-0,3997$ & 0,5192 & $-0,1228$ & 0,0505 \\
\hline - NOV. & 0,4002 & 0,063 & $-0,0506$ & 0,1443 \\
\hline - DEC. & $-0,3036$ & $-0,2929$ & 0,1196 & $-0,1725$ \\
\hline JAN. & $-0,1165$ & $-0,003$ & 0,0799 & 0,2335 \\
\hline FEB. & 0,3038 & 0,1192 & 0,1478 & $-0,2953$ \\
\hline MAR. & 0,0905 & $-0,127$ & 0,1191 & 0,0672 \\
\hline APR. & $\underline{0,3104}$ & $\mathbf{0 , 0 7 9 7}$ & 0,0376 & $-0,1407$ \\
\hline МАJ. & $-0,054$ & 0,3003 & $-0,1021$ & 0,1452 \\
\hline JUN. & $-0,0681$ & 0,3836 & $-0,0394$ & $\mathbf{0 , 0 8 1 3}$ \\
\hline JUL. & $-0,1214$ & 0,5798 & $-0,3296$ & 0,4227 \\
\hline AVG. & 0,242 & 0,2720 & $\mathbf{0 , 1 7 4 1}$ & $-0,0948$ \\
\hline SEP. & $-0,1196$ & 0,7312 & $-0,4239$ & 0,0041 \\
\hline - JESEN & $-0,0551$ & 0,6676 & $-0,1067$ & $-0,0223$ \\
\hline ZIMA & $-0,1645$ & $-0,3302$ & 0,111 & $-0,0662$ \\
\hline POMLAD & 0,1696 & 0,3154 & 0,0368 & 0,0425 \\
\hline POLETJE & 0,0667 & 0,8332 & $-0,0643$ & $\underline{0,2519}$ \\
\hline VEG. DOBA & $-0,0752$ & 0,8175 & $-0,4649$ & 0,1926 \\
\hline LETO & 0,1029 & $\mathbf{0 , 7 2 2 1}$ & $-0,1688$ & 0,2159 \\
\hline
\end{tabular}




\subsubsection{Macesni}

Pri macesnih so najboljšo podnebno odzivnost pokazali vzorci s Krnskega jezera. Podobno kakor pri smrekah s Planine pri Jezeru je tudi tu $\mathrm{v}$ ospredju pomen nadpovprečne temperature, zlasti poleti $(\mathrm{r}=0,6505)$, ob koncu pomladi in $\mathrm{V}$ septembru preteklega leta. Značilna je tudi pozitivna korelacija s povprečno letno temperaturo $(r=0,3909)$. Padavine so na tej lokaciji večinoma negativni dejavnik priraščanja, še posebej v času rasti (julij: $r=-0,5501$, veg. doba: $r=-0,3978$ ). Ugodna za prirast, ki se oblikuje naslednje leto, pa je nadpovprečna količina padavin.

Za ostali dve lokaciji je statistično značilnih korelacijskih koeficientov manj. Za pojezerje Jezera $\mathrm{v}$ Ledvicah je zlasti pomembna nadpovprečna temperatura $\mathrm{v}$ jeseni preteklega leta $(\mathrm{r}=0,3804)$ in podpovprečna pozimi $(\mathrm{r}=-0,3401)$. V času rasti pa višja $\mathrm{v}$ maju $(\mathrm{r}=0,3116)$ in nižja avgusta, ko je dobrodošlo tudi več padavin $(\mathrm{r}=$ 0,3051). Junija in julija pa je ugodneje, če je padavin manj.

Za macesne s Planine pri Jezeru je za debelinski prirast ugodneje, če je nadpovprečno toplo v obdobju od aprila do septembra $(r=0,271)$, zlasti maja $(r=0,341)$ in oktobra preteklega leta $(r=0,3533)$. Za ta mesec je, podobno kot decembra, zaželjeno manj padavin, več pa aprila in predvsem novembra $(\mathrm{r}=0,3535)$.

Tabela 4: Rezultati korelacijske analize - macesni.

Table 4: Correlation analysis results - larches.

\begin{tabular}{|c|c|c|c|c|c|c|}
\hline \multirow{2}{*}{$\begin{array}{l}N=30 \\
1961-1990\end{array}$} & \multicolumn{2}{|c|}{ PLANINA JEZERO } & \multicolumn{2}{|c|}{ KRNSKO JEZERO } & \multicolumn{2}{|l|}{ LEDVICA } \\
\hline & Padavine & Temp. & Padavine & Temp. & Padavine & Temp. \\
\hline - SEP. & 0,1642 & $-0,0758$ & - 0,0093 & 0,2551 & 0,1845 & 0,196 \\
\hline - OKT. & - 0,339 & $\mathbf{0 , 3 5 3 3}$ & - 0,1862 & $-0,0134$ & $-0,1067$ & 0,2686 \\
\hline - NOV. & 0,3535 & 0,0305 & 0,2586 & 0,1266 & 0,1493 & 0,0065 \\
\hline - DEC. & $-0,2806$ & $-0,1466$ & 0,1634 & - 0,2489 & 0,0279 & $-0,2311$ \\
\hline JAN. & - 0,0872 & - 0,1342 & $-0,1445$ & 0,1978 & 0,0142 & $-0,219$ \\
\hline FEB. & 0,0512 & $-0,1483$ & $-0,3195$ & $-0,028$ & 0,0609 & $-0,244$ \\
\hline MAR. & 0,0699 & $-0,1655$ & 0,1975 & $-0,0506$ & 0,0881 & \begin{tabular}{|l|}
$-0,368$ \\
\end{tabular} \\
\hline APR. & 0,2958 & 0,1399 & 0,0498 & 0,1879 & $-0,0329$ & $-0,04$ \\
\hline MAJ. & $-0,035$ & 0,341 & $\mathbf{0 , 0 3 3 5}$ & 0,4884 & $\mathbf{0 , 0 3 8 2}$ & 0,3116 \\
\hline JUN. & $-0,0336$ & 0,129 & $-0,147$ & 0,3816 & $-0,3497$ & 0,2196 \\
\hline JUL. & - 0,149 & 0,1395 & $-0,5501$ & 0,4297 & $-0,2776$ & $\mathbf{0 , 0 5 3}$ \\
\hline AVG. & 0,1834 & 0,0653 & $-0,0012$ & 0,1348 & 0,3051 & $-0,2639$ \\
\hline SEP. & - 0,0298 & 0,0469 & $-0,1575$ & 0,0906 & 0,1207 & 0,1275 \\
\hline - JESEN & 0,1283 & 0,1148 & 0,060 & 0,1982 & 0,1649 & 0,3804 \\
\hline ZIMA & $-0,2004$ & - 0,0634 & - 0,1385 & - 0,0148 & 0,003 & - 0,3401 \\
\hline POMLAD & 0,1565 & 0,0948 & 0,1299 & 0,2503 & 0,0412 & $-0,1326$ \\
\hline POLETJE & $\mathbf{0 , 0 3 3 8}$ & 0,2083 & $-0,3608$ & 0,5605 & $-0,1406$ & $\mathbf{0 , 0 0 1}$ \\
\hline VEG.DOBA & $-0,0156$ & 0,271 & $-0,3978$ & 0,5346 & 0,0155 & 0,1705 \\
\hline LETO & 0,1186 & 0,2093 & 0,0022 & 0,3909 & 0,0261 & - 0,1157 \\
\hline
\end{tabular}




\section{RAZPRAVA}

$\mathrm{Z}$ naraščanjem nadmorske višine se slabšajo temperaturne razmere za rast rastlin. $\mathrm{Na}$ določeni nadmorski višini postanejo tako nizke, da neposredno omejujejo rast. Za Slovenijo so dognali, da je zgornja klimatska (termična) gozdna meja od 1700 do 1900 m, drevesna meja pa je še nekoliko višje (Gams,1977; Lovrenčak,1977, 1987). Po Frittsu (1976) je spodnji optimum za fotosintezo dreves ob zgornji gozdni meji v zmernih geografskih širinah med 12 in $13{ }^{\circ} \mathrm{C}$, po Franzu (1979) pa celo nekaj nižji, med 8 in $9{ }^{\circ} \mathrm{C}$. Po podatkih meteorološke postaje Dom na Komni (nadmorska višina $1520 \mathrm{~m}$ ) nihajo povprečne poletne temperature okoli $11,7{ }^{0} \mathrm{C}$, zaradi česar ni presenečenje, da se večina statistično značilnih korelacijskih koeficientov nanaša na zvezo med temperaturo in širino letnic $\mathrm{v}$ rastni sezoni, bodisi da gre za zveze $\mathrm{s}$ posameznimi meseci, najpogosteje majem, ko se vegetacija začenja, poletjem ali celotno toplo polovico leta od aprila do vključno septembra. Nadpovprečna temperatura $\mathrm{v}$ času rasti pomeni daljšo rastno sezono in ugodnejše razmere za rast, kar se kaže v širših letnicah.

Presenečajo pa razlike med posameznimi lokacijami in drevesnimi vrstami znotraj njih. Najtesneje so s temperaturo v rastni sezoni, pa tudi zunaj nje, povezane smreke s Planine pri Jezeru, kjer imajo vsi meseci od maja do septembra značilne korelacije. S korelacijo za poletno temperaturo lahko pojasnimo skoraj $70 \%$ variacije debelinskega prirastka. Za macesne s te lokacije pa je predvsem pomemben nadpovprečno topel začetek rastne sezone v maju, nakazuje pa se tudi šibka zveza s celotno toplo polovico leta (vegetacijsko sezono). Visoko odvisnost smrek od temperatur na Planini Jezero lahko delno pojasni mikrolega rastišča, saj rastejo smreke v razmeroma zaprti kotanji, za katero predvidevamo, da se $\mathrm{v}$ njej nabira hladen zrak in deluje kot mrazišče. Macesne pa smo vzorčili predvsem po robu jezerske kotanje, kjer je inverzija manj izrazita.

Nekoliko manjšo odvisnost in manj trdne zveze s temperaturo v času rasti od smrek s Planine pri Jezeru kažejo macesni s Krnskega jezera. Tu je predvsem pomembna nadpovprečna temperatura konec pomladi in v prvi polovici poletja. Presenetljivo pa se odzivajo na temperature $v$ rastni sezoni macesni s pojezerja Jezera v Ledvicah. Za začetek sezone v maju je ugodna nadpovprečna temperatura, za obdobje po optimumu priraščanja $\mathrm{v}$ avgustu pa podpovprečna $(\mathrm{r}=-0,2639)$. Rezultat bi lahko pripisali slučaju, če ne bi istočasno izračunali za avgustovske padavine pozitivne korelacije (r $=0,3051$ ), kar tudi odstopa od pričakovanj za predele ob zgornji gozdni meji, saj pade v tem mesecu v Dolini Triglavskih jezer povprečno več kot $200 \mathrm{~mm}$ padavin. Očitno pa moče ni dovolj, saj rastejo macesni na izrazito kraškem (škrapljastem) rastišču, kjer se padavine hitro odcedijo $v$ podzemlje. Višje temperature pa vodni stres še krepijo. 
Razen od temperature v rastni sezoni je debelinski prirast odvisen tudi od temperature ob koncu pretekle sezone in pozimi. Nadpovprečno topla jesen, predvsem september in oktober, po rezultatih za smreke in macesne s Planine pri Jezeru pa tudi podpovprečno namočena, ugodno vpliva na konec rasti in pripravo dreves na zimsko mirovanje. Po Frittsu (1976) drevesa $v$ tem času skladiščijo rezervne snovi in oblikujejo listne zasnove, ki se razvijejo v naslednji vegetacijski sezoni. Tople (in suhe) razmere ob koncu rasti drevesom omogočijo ugodnejši potek teh procesov, kar se kaže tudi v večjem debelinskem prirastku v naslednji sezoni.

Pri macesnih s pojezerja Jezera v Ledvicah in smrekah s Planine pri Jezeru se kaže tudi negativni skupni vpliv višjih zimskih temperatur, zlasti decembra, pri macesnih s Krnskega jezera in Ledvice pa tudi februarske in marčevske temperature. Fritts (1976) pojasnjuje ta pojav s tem, da povzročijo višje zračne temperature, še posebej skupaj z vetrom, v času, ko so korenine hladne ali celo zamrznjene, povečano transpiracijo, ki povzroči fiziološko sušnost in poškodbe iglic oziroma tkiv. Hladne korenine pa ne morejo zagotoviti zadostne količine vlage za nadomestitev izgube, ki nastane zaradi povečanega izhlapevanja.

Glede na veliko namočenost južnega oziroma JZ roba Julijskih Alp, kjer pade letno od 2500 do več kot $3000 \mathrm{~mm}$ padavin, od tega nekaj manj kot polovico od aprila do septembra, smo pričakovali tesnejše zveze s padavinami. K temu so nas napeljevali tudi rezultati številnih študij iz podobnih okolij po svetu in tudi doma, kjer je Ogrin (1992) za smreke s Komne in Vršiča ter macesne s Krvavca, Komne in Vršiča ugotovil negativen vpliv nadpovprečne količine padavin $\mathrm{v}$ času rasti. Tem rezultatom so se v naši raziskavi še najbolj približali macesni in smreke s pojezerja Krnskega Jezera, ki prejme največ padavin od vseh obravnavanih lokacij. Večja namočenost in oblačnost $\mathrm{v}$ času rasti namreč pomenita nižjo temperaturo in slabše razmere za rast. Glede na naše rezultate so zlasti pomembne padavine $v$ juliju. Blizu pričakovanim rezultatom so tudi macesni s pojezerja Jezera $\mathrm{v}$ Ledvicah, kjer sta junij in julij $\mathrm{v}$ negativni korelaciji s padavinami, avgust, ko pade običajno nekaj manj padavin, pa, kot smo že omenili, v pozitivni.

Pri smrekah in macesnih s Planine pri Jezeru in macesnih s Krnskega jezera je zanimiva odzivnost na padavine $\mathrm{v}$ posameznih mesecih hladne polovice leta. Po že omenjenem bolj sušnem (in toplem) oktobru, ki sodi v čas priprav drevja na zimsko mirovanje, je novembra dobrodošlo več padavin (višja snežna odeja), podobno tudi februarja (smreke - Planina pri Jezeru) in aprila (smreke in macesni - Planina Jezero). Zvezo bi lahko pojasnjevali z boljšo zaščito pred mrazom, ki jo koreninam nudi višja snežna odeja, nekoliko pa to razlago razvrednoti dejstvo, da so decembrske padavine pri obeh drevesnih vrstah s Planine pri Jezeru v negativni korelaciji. Težko je potegniti vzporednico tudi s količino padavin, saj sta november in april med najbolj padavinskimi meseci, februar je najbolj suh, december pa je na ravni letnega 
mesečnega povprečja. Da verjetno ne gre za slučajne zveze, pa opozarjajo podobni rezultati za smreke s Komne (Ogrin, 1992).

Slika 3: Odzivna funkcija za smreke s Planine pri Jezeru.

Figure 3: Response function of spruces from location Planina pri Jezeru.

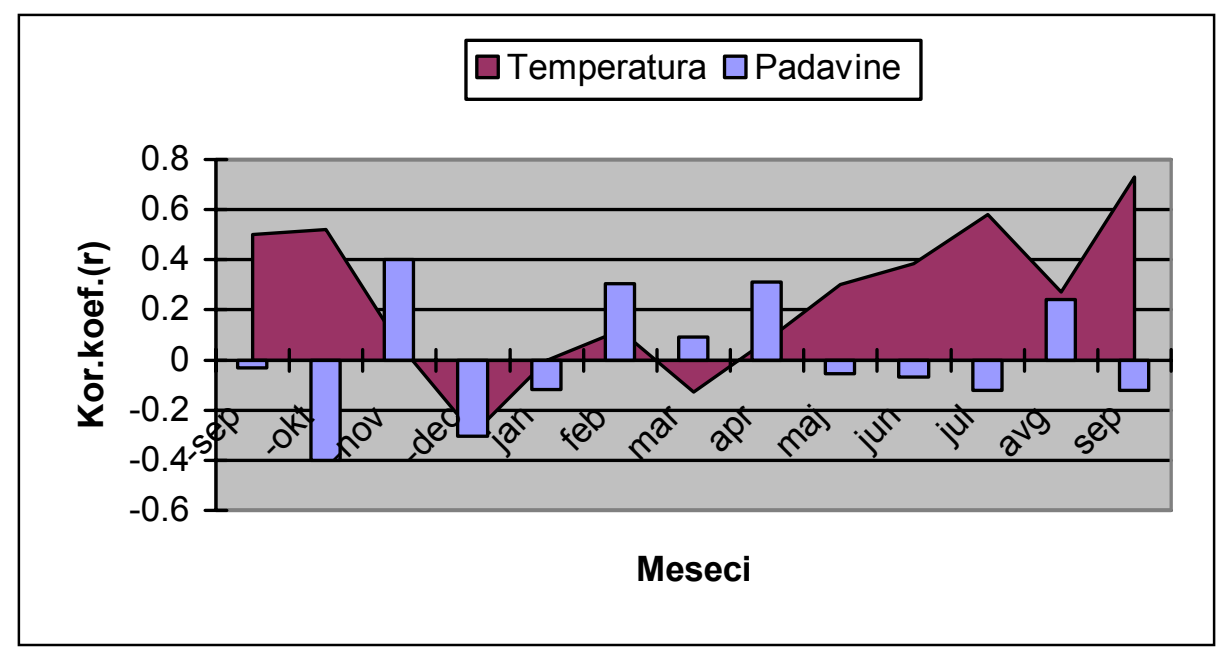

\section{SKLEPI}

S pojezerij Jezera na Planini pri Jezeru, Jezera v Ledvicah in Krnskega jezera smo po ustaljenih postopkih sestavili dve smrekovi in tri macesnove kronologije, ki večinoma pokrivajo obdobje po letu 1920. Med lokalnimi kronologijami je določena podobnost, vendar ne dovolj velika, da bi lahko sestavili regionalno kronologijo za vsa tri pojezerja.

Izračunane korelacije za zvezo med temperaturo in padavinami ter širino letnic kažejo, da je podnebni signal, zapisan $\mathrm{v}$ letnicah, najbolj izrazit pri smrekovi kronologiji s Planine pri Jezeru in macesnovi s pojezerja Krnskega jezera. Pri obeh, še zlasti pri smrekah s Planine pri Jezeru, je prevladujoč dejavnik temperatura. Ta pomembno vpliva na prirast zlasti $\mathrm{v}$ dveh obdobjih: $\mathrm{v}$ rastni sezoni in $\mathrm{v}$ času priprav drevja na zimsko mirovanje septembra in oktobra. Tedaj je ugodno, če so temperature nadpovprečne. Nasprotno pa morajo biti zimske temperature podpovprečne. 
Glede na veliko namočenost Julijskih Alp je vpliv padavin proti pričakovanju majhen, še posebej $\mathrm{v}$ rastni sezoni. Nadpovprečna količina padavin $\mathrm{v}$ tem času deluje zaviralno na prirast predvsem na drevesa $\mathrm{z}$ območja Krnskega jezera, ki je najbolj namočen predel v obravnavani pokrajini. Drugod je ta vpliv zelo majhen, na primeru macesnov $\mathrm{s}$ pojezerja Jezera $\mathrm{v}$ Ledvicah pa avgusta celo inverzen, saj je, verjetno zaradi izrazitega kraškega površja, $v$ tem mesecu izražena potreba po več padavinah. Rezultati nakazujejo tudi zvezo $\mathrm{s}$ podpovprečnimi padavinami $\mathrm{v}$ času priprav na zimsko mirovanje, nejasen pa ostaja odnos med širino letnic in padavinami v hladni polovici leta.

Iz rezultatov za macesnovo kronologijo s Planine pri Jezeru, smrekovo iz območja Krnskega jezera in delno macesnovo iz pojezerja Jezera $v$ Ledvicah je razvidno, da bolj kot povprečno vreme vplivajo na debelinski prirast razne stresne situacije, npr. vetrolomi, snegolomi, ohladitve ipd., ki jih klimatska statistika ne zajame. To se kaže tudi v bolj pogostih dvojnih in manjkajočih letnicah, depresijah v prirastku oziroma nepravilnih prirastnih krivuljah.

\section{VIRI IN LITERATURA}

1. Bailie M.G.L., Pillcher J.R., 1973: A simple cross-dating programme for treering research, Tree-Rings Bulletin 23, 7-14.

2. Biondi F., 1993: Climatic signals in tree rings of Fagus sylvatica from the Central Appennines, Italy, Acta Oecologica 14, 57-71.

3. Braker O.U., 1982: Alpine Europe, v: Climate from Tree Rings, Cambridge, 210 str.

4. Cook E.R., Kairiukstis L.A., 1990: Methods of Dendrochronology, Kluwer, Dordrecht, 391 str.

5. Franz H., 1979: Oekologie der hochgebirde, Stuttgart.

6. Fritts H.C., 1976: Tree Rings and Climate, Academic Press, London, 567 str.

7. Gams I., 1977: O zgornji gozdni meji na JV Koroškem, Geografski zbornik XVI, Ljubljana, 151-193.

8. Hansen-Bristow K.J., Ives J.D., Wilson J.P., 1988: Climatic Variability and Tree Response within the Forest-Alpine Tundra Ecotope. Annals of American Geographers, vol.78, št.3.

9. Hughes M.K., Kelly P.M., Pilcher J.R., La Marche V.C., 1971: Climate from Tree Rings, Cambridge, 210 str.

10. Klimatogeografija Slovenije, 1995: Padavine 1961-90, Ljubljana, 46.

11. Klimatografija Slovenije, 1995: Temperatura zraka 1961-90, Ljubljana, 41. 
12. Lovrenčak F., 1977: Zgornja gozdna meja v Kamniških Alpah v geografski luči, Geografski zbornik 1976, Ljubljana, 5-150.

13. Lovrenčak F., 1987: Zgornja gozdna meja v Julijskih Alpah in na visokih kraških planotah Slovenije, Geografski zbornik 1986, Ljubljana, 5-58.

14. Ogrin D., 1989: Dendroklimatologija in možnosti uporabe njene metode $\mathrm{v}$ Sloveniji, Geografski vestnik 61, Ljubljana, 133-140.

15. Ogrin D., 1992: Vpliv padavinskih in temperaturnih razmer na debelinski prirast dreves (na primeru treh pokrajinskih tipov v Sloveniji), Geografski zbornik 31 (1991), Ljubljana, 107-161.

16. Rolland C., 1993: Tree-rings and climate relationship for Abies Alba in the Internal Alps, Tree-Rings Bulletin 53, 1-11.

17. Shiyatov S.G., Mazepa V.S., 1987: Some New Approaches in the Consideration of More Reliable Dendroclimatological Series and in the Analysis of Cycle Components, Varšava.

\title{
CLIMATIC CONDITIONING OF RADIAL INCREMENTS OF TREES NEAR SLOVENIAN HIGH-MOUNTAINOUS ALPINE LAKES
}

\begin{abstract}
Summary
The investigation was carried out in the upper tree-line zone in the lake areas of Jezera on Planina pri Jezeru (1450 m above sea level), Jezero (1394 m) and Krnsko Jezero, all in the Julian Alps (NW Slovenia). About 20 spruces (Picea abies) and larches (Larix europea) from each lake area were analysed, about a hundred samples in all. Five chronologies of indexes of annual rings (of 3 larches and 2 spruces) were made, covering the period from 1920 onwards. Similarity of chronologies is so insignificant ( $\mathrm{t}$-coefficient acc.to Baillie-Pilcher less than 8), that a uniform regional chronology for all the three lake areas cannot be made.

Correlations for relations between temperatures and precipitation, and the width of annual rings show that the climate signal which is registered in the annual rings is most explicit in the chronology of spruces from Planina pri Jezeru, and in the chronology of larches from the lake area of Krnsko jezero. Temperature is the dominant factor at both tree species, spruces from Planina pri Jezeru in particular. It significantly influences the growth, mainly in two periods: the vegetation season $(r=$ 0,8175 ), and the time of preparation of trees for winter dormancy, i.e. September and October of the previous year $(r=0,6676)$. Above-average temperatures are favourable at that time. In contrast to this, below-average temperatures $(r=-0.3302)$ are favourable in wintertime.
\end{abstract}


If large precipitation amounts in the Julian Alps are taken into account, it can be concluded that the influence of precipitation is insignificant especially in the growing season, which is contrary to our expectations. The above-average amount of precipitation in that time impedes the growth of annual rings, especially at spruces ( $\mathrm{r}$ $=-0,4649)$ and larches $(r=-0,3608)$ from the area of Krnsko Jezero which is the wettest area of the discussed region. This influence is poorly manifested in other parts, and in the case of larches from the lake area of Jezero $v$ Ledvicah, it is even inverse $(\mathrm{r}=0,3051)$ in August, since the need for larger amount of precipitation is clearly expressed in this month, probably because of the explicit karstic surface. The results indicate the relation with below-average precipitation in the time of preparation for winter dormancy, while the relation between the width of increments and precipitation in the cold half of the year remains unclear.

It is evident from the results of chronology of larches from Planina pri Jezeru, chronology of spruces from the area of Krnsko Jezero, and partly chronology of larches from the lake area of Jezero $v$ Ledvicah, that more than by average weather conditions, the width of increments are influenced by the stress situations, e.g. wind-, or snow- caused breaking, cooling and similar phenomena, which are not registered in the climatic statistics. This is often manifested either in double or missing annual rings, or depressions in increments, or irregular increment curves. 